Research Article

\title{
An Experimental Study of Horizontal Bearing Capacity of Vertical Steel Floral Tube Micropiles with Double Grouting
}

\author{
Kaiyang Wang $\mathbb{D}^{1,2,3,4,5}$ and Yanjun Shang ${ }^{1,2,3}$ \\ ${ }^{1}$ Key Laboratory of Shale Gas and Geoengineering, Institute of Geology and Geophysics, Chinese Academy of Sciences, \\ Beijing 100029, China \\ ${ }^{2}$ University of Chinese Academy of Sciences, Beijing 100049, China \\ ${ }^{3}$ Institutions of Earth Science, Chinese Academy of Sciences, Beijing 100029, China \\ ${ }^{4}$ Broadvision Engineering Consultants of Yunnan Province, Kunming 650011, China \\ ${ }^{5}$ National Engineering Laboratory for Surface Transportation Weather Impacts Prevention, Kunming 650011, China
}

Correspondence should be addressed to Kaiyang Wang; kai.yang2008@163.com

Received 4 May 2018; Accepted 4 November 2018; Published 25 November 2018

Academic Editor: Constantin Chalioris

Copyright (c) 2018 Kaiyang Wang and Yanjun Shang. This is an open access article distributed under the Creative Commons Attribution License, which permits unrestricted use, distribution, and reproduction in any medium, provided the original work is properly cited.

\begin{abstract}
This paper examines the performance of a novel technology, vertical steel floral tube micropiles with double grouting. It is the combination of micropile technology and double grouting technology. A large-scale model tank was applied to impart horizontal bearing capacity, and the slope soil pressure and flexural performance of the micropile were investigated under four experimental conditions. The peak grouting pressure during the double grouting process was defined as the fracturing pressure of the double grouting, and it was positively correlated to the interval time between first grouting and secondary grouting. Compared with traditional grouting, double grouting increased the horizontal bearing capacity of the single micropile with the vertical steel floral tube by $24.42 \%$. The horizontal bearing capacity was also $20.25 \%$ higher for the structure with three micropiles, compared with a 3 fold value of horizontal sliding resistance. In the test, the maximum bending moment acting on the pile above the sliding surface was located 2.0-2.5 $\mathrm{m}$ away from the pile top, and the largest negative bending moment acting on the pile below the slip surface was located $4.0 \mathrm{~m}$ away from the pile top. The ultimate bending moment of the single pile increased by $12.8 \mathrm{kN} \cdot \mathrm{m}$ with double grouting, and the bending resistance increased by $96.2 \%$. The experimental results showed that the double grouting technology significantly improved the horizontal bearing capacity of the micropile with the steel floral tube, and the soil reinforcement performance between piles was more pronounced. Also, the shear capacity and the flexural capacity were significantly improved compared with the original technology.
\end{abstract}

\section{Background}

In practice, micropiles have characteristics of high mechanization, rapid and safe construction, and light equipment loads. As such, micropiles have a broad applicability and have been widely used in engineering for building reinforcement, retaining structures, and slope support. Micropile technology was first proposed in the 1950s [1] and introduced into Germany and the commonwealth countries in the 1960s. Micropile technology was introduced in the United States after the patent removal in the 1970s and rapidly spread internationally in the 1980s and 1990s [2-5].
Early research focused on the vertical loading mechanism of micropiles. "Micropile Design and Construction Guide" preliminarily studied the vertical bearing mechanism of micropiles [6]. In addition, Thompson and White [7] carried out a pullout test and a compression test to investigate the vertical bearing characteristics of micropiles under the condition of pressure grouting. Mokwa and Duncan [8] studied the functional relationship between pile spacing, pile number, and the bearing performance. The mechanical behavior of a single pile under cyclic axial loading was examined by Lee [9]. Benslimane [10] studied the seismic response of a single micropile and a pile group, under the 
actions of axial and lateral loading. In 2002, Japan promulgated "Design and Construction Manual of Repairing Existing Pile Foundations for High Bearing Micropiles for Post-Earthquake," which provided a design method for two different types of earthquake [11]. These studies provided theoretical bases for the exploitative usage of micropiles. During the subsequent years, many scholars experimentally studied the mechanism of horizontal carrying capacity. For example, the relationship between lateral load and pile length for a single micropile was investigated by Awad [2]. Jensen [4] proposed an inclined layout of micropiles in the direction of slope sliding, to mobilize the axial bearing capacity of micropiles to resist the slope sliding. Also, Richards and Rothbauer [12] experimentally determined that the lateral bearing capacity of micropiles was very sensitive to the type and the shear strength of soil at the location 2-5 $\mathrm{m}$ above the pile body, but there was no further explanation for the influence of specific soil type on the micropile. Long et al. [13] experimentally studied the horizontal bearing capacity of micropiles with variable cross sections and a length of $15.2 \mathrm{~m}$, as well as the failure characteristics of a single micropile under a concentrated load. Yalcin and Meyerhof [14] used the model test to study the stress characteristics of an inclined pile under an inclined load. Moreover, the lateral bearing capacity of a topconnected micropile system was studied by Kim et al. [15]. Yin et al. [16] proposed a new nonlinear method to evaluate lateral behaviour of a pile located in or nearby a slope, and the study clearly showed that the slope angle has a significant effect on the deflection and lateral capacity of piles. Kahribt and Abbas [17] found that, under combined vertical and cyclic lateral loads, the lateral displacement of piles decreased with an increase in the vertical load, whereas it causes large vertical displacements at all slenderness ratios. These model tests mainly focused on the influencing factors of the working properties of the micropile, including the pile spacing, the load characteristics, and the pile angle. However, there were some problems in the above research studies, such as the small size of the experimental models and the incomplete research on the combined application technology. With the development of computer technology, Dan and Shie [18]; Rollins et al. [19, 20], Zhou et al. [21], Shi et al. [22], and Du et al. [23] used numerical simulations to study the effects of vertical and horizontal bearing, which broadened micropile research ideas and made use of multifactor analysis and repeatable calculation. However, the theoretical results of these studies could not be verified, and the model data were difficult to apply to actual projects. With the accumulation of engineering experience and the deepening of theoretical research, the applications of micropiles in engineering practice were diversified and often combined with other mature control technologies, such as the anchor cable, the soil nailing wall, the reinforced earth retaining wall, and grouting technology. Zhu and $\mathrm{Wu}$ [24] first applied oblique steel floral tube micropile grouting technology to highway slope protection engineering and monitored the engineered structure. However, there was no explanation of the antisliding mechanism and the force structure state. Additionally, $\mathrm{Li}$ et al. [25] combined experimental and numerical simulation methods to study the displacement of the supporting structure, the internal force deformation, and the stress characteristics of a soil nail with two different positions of curtain, and they integrated these two technologies to practical engineering applications. Zhang and Chen [26] put forward a comprehensive support structure combined with micropiles and reinforced soil retaining wall technology, which was also applied to engineering practice.

Based on previous research results, this study further explores the steel floral tube micropile and examines a novel technology, vertical steel floral tube micropiles with double grouting, which is the combination of micropile group antisliding technology and double grouting control technology. The traditional steel floral tube reinforcement technology has several issues, including the slurry permeating through the bottom hole, the small diffusion area of slurry, and the imperfection of soil consolidation between piles. In novel technology, porous steel floral tube micropiles were selected, and double grouting was applied in the large diffusion area; this improved the bearing capacity of the single pile, the soil reinforcement between piles, the stress performance of the pipe group, and the overall flexural capacity. In this paper, a large-scale model test tank $(6 \mathrm{~m} \times$ $1.5 \mathrm{~m} \times 9.48 \mathrm{~m}$ ) was used. To obtain a deeper understanding of the combined micropile technology and double grouting technology, and to provide a reference for subsequent theoretical research as well as the engineering application, several performance characteristics were evaluated based on four groups of experiments. These characteristics include the double grouting results, horizontal bearing capacity, slope soil pressure, and the flexural performance of micropiles under the conditions of no pile, single pile with traditional one grouting, single pile with double grouting, and three piles with double grouting.

\section{Vertical Steel Floral Tube Micropile Technology}

The steel floral tube micropile is a new technology for slope reinforcement. It can be divided into two types: vertical and oblique steel floral tube micropiles. The oblique micropile with a steel floral tube has been researched and applied in practical engineering [24]. Therefore, this paper focuses on the vertical steel floral tube micropile.

The vertical steel floral tube with double grouting is the combination of two antisliding technologies, namely, "micropile group" and "double grouting". This technology is different from traditional grouting technology when drilling a micropile, which forms a grouting with a larger diffusion area. Thus, the bearing capacity of the single steel floral tube, the soil reinforcement between piles, the antisliding, and the shearing resistance of the double grouting are improved. The structure of the single steel floral tube is shown in Figure 1.

\section{Introduction}

3.1. Model Tank. The experimental tests were conducted in a model tank composed of a reaction wall, sidewall, and loading plate. The size of the model tank was $6 \mathrm{~m}$ (height) $\times$ 


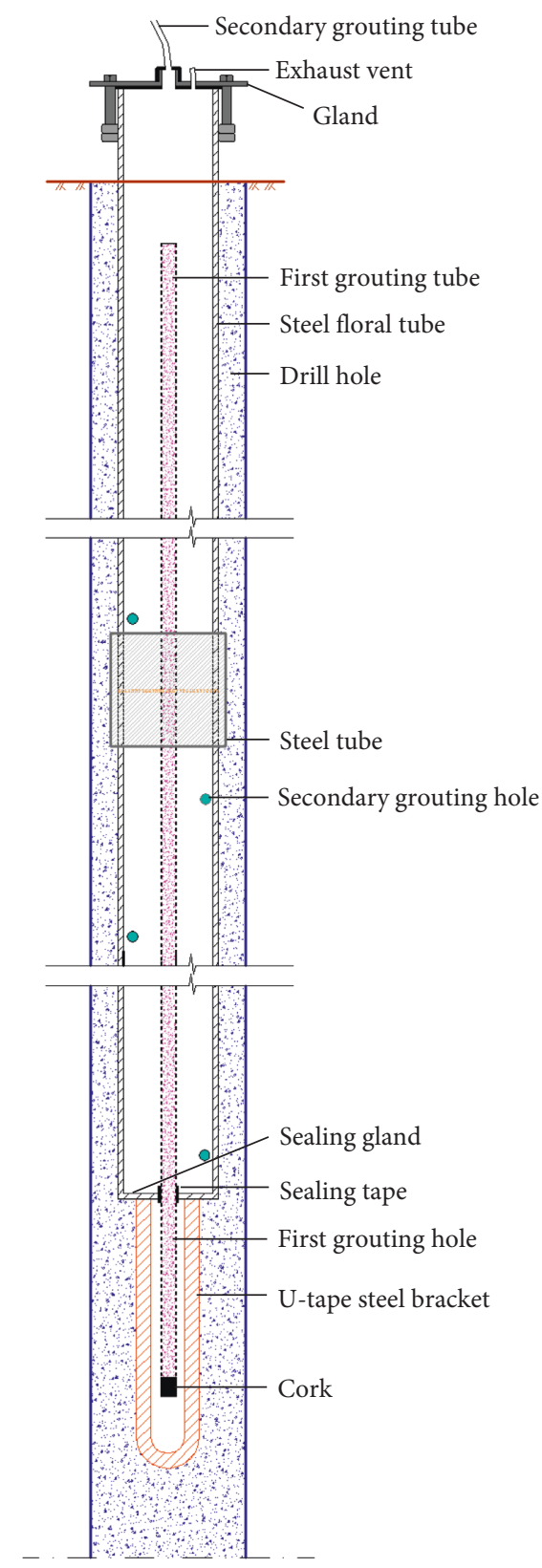

Figure 1: Structure of the single steel floral tube.

$1.5 \mathrm{~m}$ (width) $\times 9.48 \mathrm{~m}$ (length), as shown in Figure 2 . The size of the reaction wall was $6 \mathrm{~m}$ (height) $\times 2.1 \mathrm{~m}$ (width) $\times$ $3 \mathrm{~m}$ (length). According to the design of the antisliding pile, the back portion of the reaction wall (away from the loading plate) was filled with rubble concrete. The sidewall of the model tank was $0.3 \mathrm{~m}$ thick and $6 \mathrm{~m}$ high and was made of reinforced concrete. To ensure the sidewall stability of the model tank during the test procedure, both sides were filled with rubble concrete of size $3 \mathrm{~m}$ (height) $\times 1.5 \mathrm{~m}$ (width) $\times$ $6.5 \mathrm{~m}$ (length). Also, the inside of the sidewall was plastered by cement mortar. The size of the loading plate was $3 \mathrm{~m}$ (height) $\times 1.45 \mathrm{~m}$ (width) $\times 0.08 \mathrm{~m}$ (length) and was hoisted into the model tank by a crane. The bottom of the loading plate was located on the sliding platform, and they were not directly connected in order to avoid the influence of sliding friction between them on test results. The top of the loading plate was fixed by the roller equipped on the sidewall of the model tank, and the loading plate could not rotate under the joint limitation of the top connecting rod, roller, roller sliding track, and sidewall of the model tank, as shown in Figures 3 and 4. The loading plate can produce displacement under the action of small horizontal thrust by the roller. During the test process, the deflection of the steel plate was smaller than $3 \mathrm{~mm}$, which met the test requirements. Additionally, the displacements of the reaction wall and the sidewall were monitored, and the displacement changes were measured. During the test, horizontal thrust was produced by the jack between the loading plate and the reaction wall. The bottom of the jack and two pieces of the square steel plate with a length of $0.05 \mathrm{~m}$ were welded at right angles, and then the steel plates were fixed to the reaction wall. The displacement loading was selected in the test, and in each loading process, the loading plate moved with a displacement of $20 \mathrm{~mm}$. The restriction of displacement ensures that the actual motion mode of the loading plate during the test process is horizontal movement without any inclination. The filling soil in the model tank was sand and clay, which was mixed at a ratio of $5: 1$, and $12 \%$ water content. Based on the direct shear test, the filling soil cohesion $(c)$ was measured as $5 \mathrm{kPa}$, and the angle of internal friction $(\varphi)$ was $34^{\circ}$. The horizontal sliding surface was simulated with saturated soft clay, with a thickness of $0.2 \mathrm{~m}$ and the composition of fully weathered shale. Measurements of the variables $c=15 \mathrm{kPa}$ and $\varphi=34^{\circ}$ were obtained by the direct shear test. A steel tube with an external diameter of $89 \mathrm{~mm}$ and a wall thickness of $4.5 \mathrm{~mm}$ was used for the steel floral tube, and the drill hole diameter of the lower pile was $130 \mathrm{~mm}$. The double grouting holes were distributed spirally in the steel tube wall, with an aperture of $7 \mathrm{~mm}$ and spacing of $15 \mathrm{~cm}$.

3.2. Experimental Design. The design of the model test is shown in Figure 5. Data were acquired from the soil pressure gauge, strain gauge, pressure gauge, dial indicator, and the inclinometer, which were arranged as shown in Figure 2. For the installation of the steel floral tube, the concrete pier was set at the bottom of the model tank, and the steel floral tube was directly inserted into the pier concrete following drilling. During the test, the grouting outside the tube was selected for the first grouting, and the water-cement ratio was 0.55 . The grouting inside the tube was selected for the secondary grouting, with a water-cement ratio of 0.7 . Glass cement was used to seal the secondary grouting hole. The double grouting completion was based on the grouting pressure exceeding the permissible pressure $(8 \mathrm{MPa})$ of the grouting injector and the grouting pipe, or the slurry leakage. The displacement loading was used during the loading process, and the loading plate was moved horizontally with a unit length of $20 \mathrm{~mm}$.

Four experiments were conducted to simulate the horizontal bearing capacities of the independent steel floral tube group and the multiple-row steel floral tube group. Test A was used to investigate the deformation and the stress 


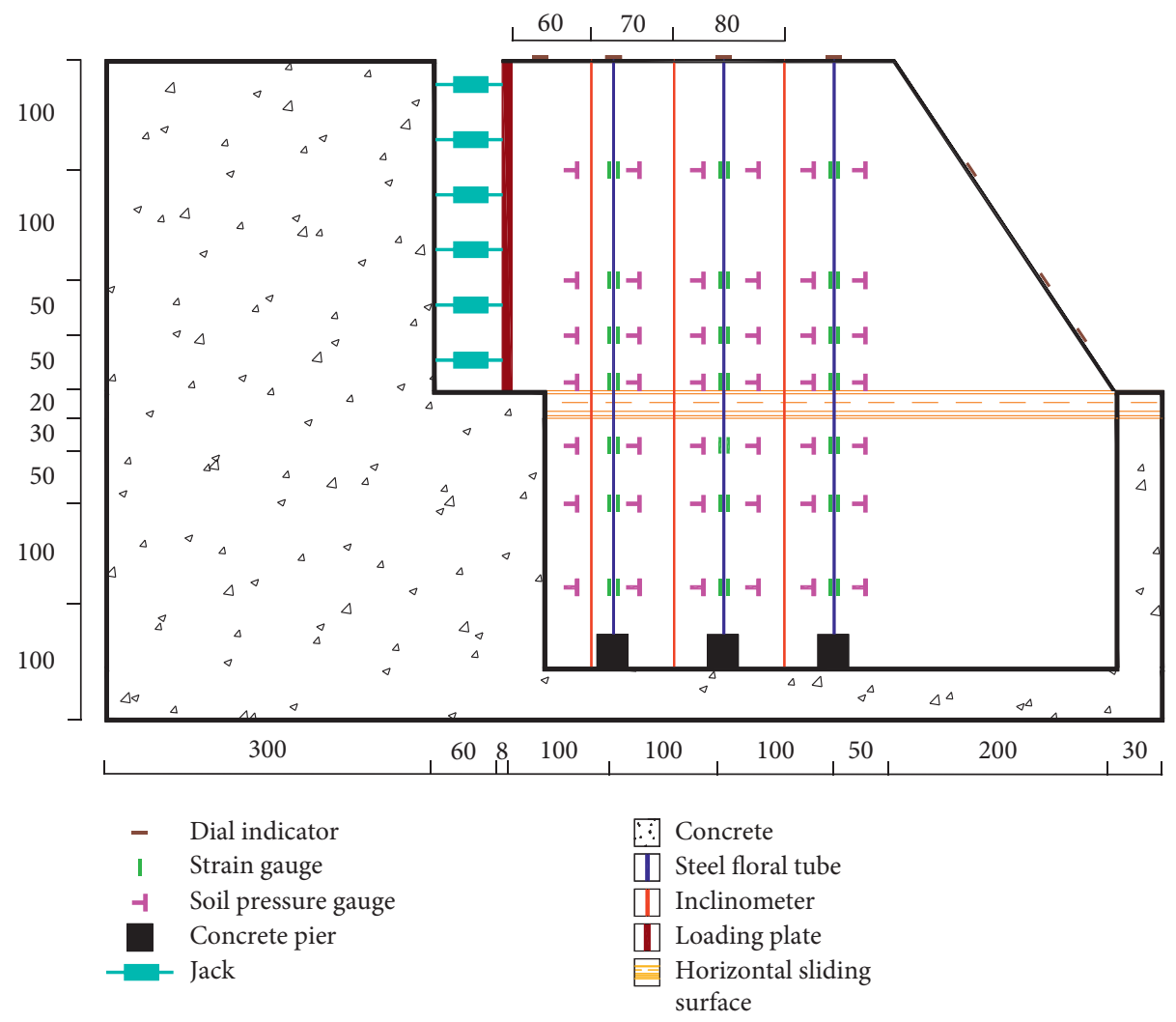

FIgURE 2: Schematic of the model tank (example arrangement diagram of Test D; all values in $\mathrm{cm}$ ).

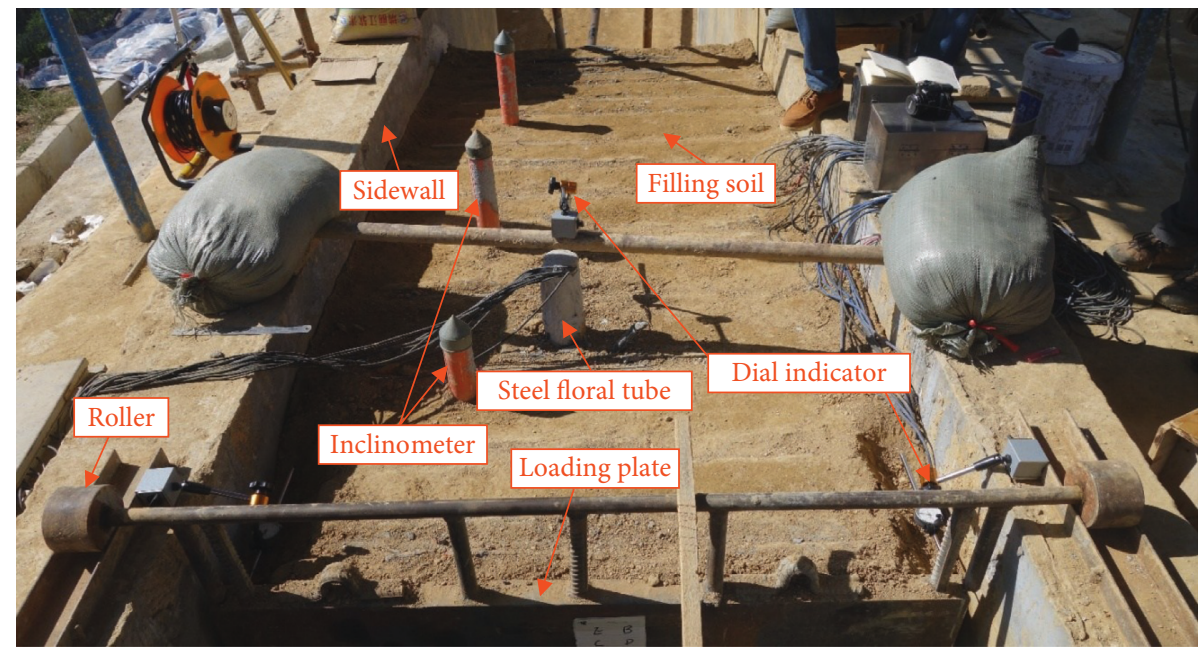

FIgURe 3: Field test figure of the model tank.

change of the slope without piles, under the action of the horizontal loading, and also to verify the reliability of the test system. Test B focused on the deformation mechanisms and the changes of the horizontal bearing capacity of the slope with a single pile, under the conditions of one grouting. The aim of Test $C$ is to study the deformation mechanisms and the changes of the horizontal bearing capacity of the slope with a single pile, under the conditions of new technology of double grouting. Test $\mathrm{D}$ focused on the deformation mechanism of the slope with three piles and double grouting under the action of horizontal loading. The evaluation of the double grouting technology is achieved through the comparison between Test B and Test C. The test scheme is shown in Table 1.

Tests C and D carried out double grouting for the steel floral tube pile. For Test $\mathrm{C}$, the interval time between first grouting and secondary grouting was $7.5 \mathrm{~h}$. The grouting hole was set at the area 2.5-4 m below the pile top (the height of the sliding surface was $3 \mathrm{~m}$ ), and the effective sealing length was $2.5 \mathrm{~m}$. The locations of the three piles (No. 1 pile, 


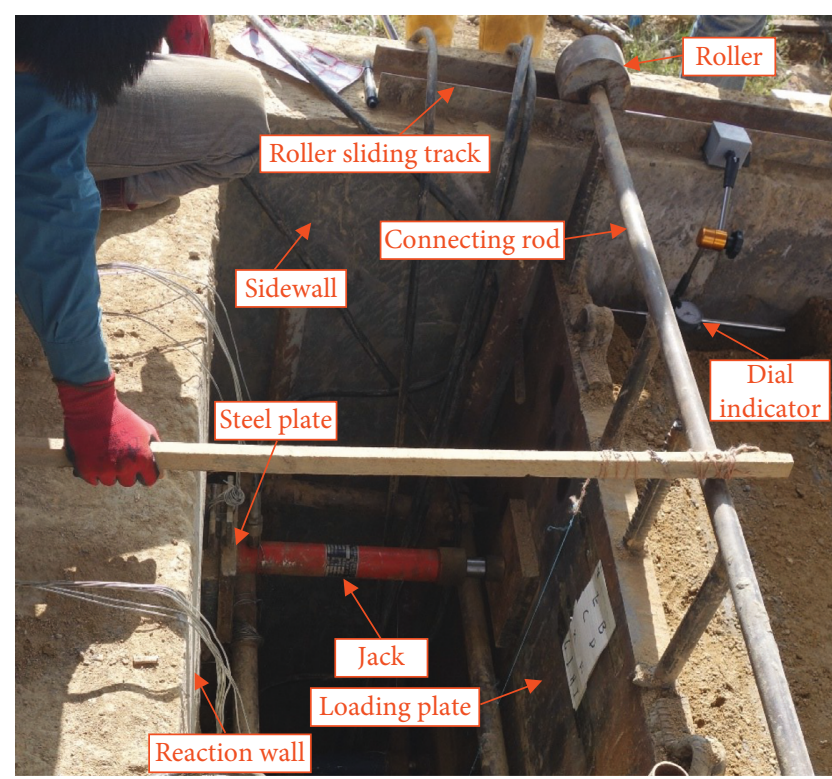

FIGURE 4: The connection figure between the jack and the loading plate.

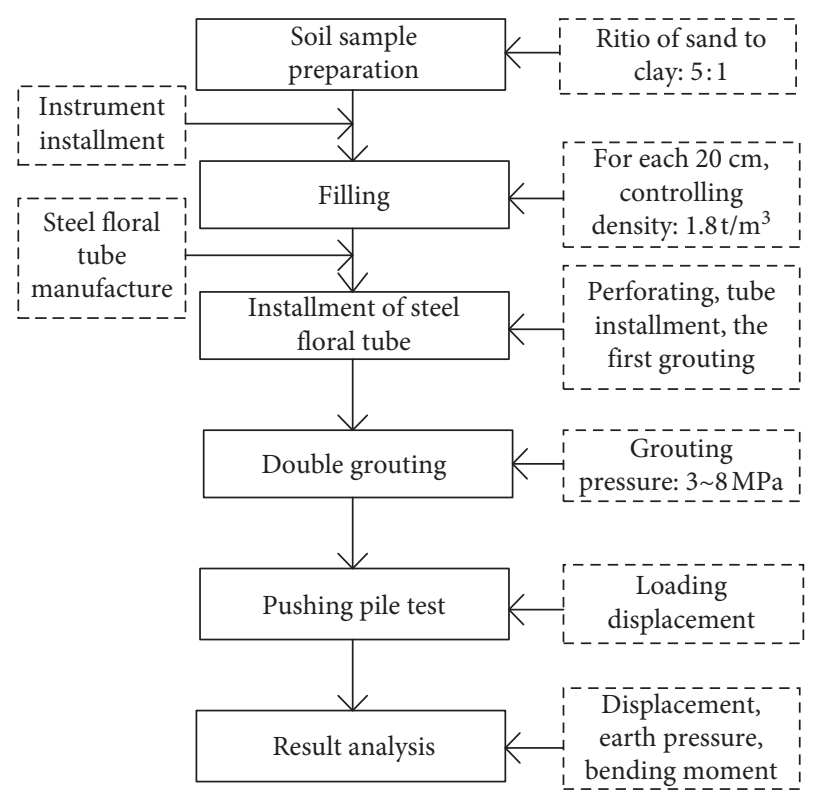

Figure 5: Flow chart of the model test.

TABle 1: Experimental test protocol.

\begin{tabular}{lcccc}
\hline $\begin{array}{c}\text { The burying } \\
\text { of } \\
\text { number } \\
\text { the steel } \\
\text { floral } \\
\text { tube (No.) }\end{array}$ & $\begin{array}{c}\text { The } \\
\text { double } \\
\text { grouting }\end{array}$ & $\begin{array}{c}\text { The burying } \\
\text { of } \\
\text { the oblique } \\
\text { tube (No.) }\end{array}$ & $\begin{array}{c}\text { The burying } \\
\text { of } \\
\text { the soil } \\
\text { pressure } \\
\text { gauge (No.) }\end{array}$ \\
\hline $\begin{array}{l}\text { Test A } \\
\text { Test B }\end{array}$ & - & - & 2,3 & $1,4,6$ \\
Test C & 1 & - & $1,2,3$ & $1,2,4,6$ \\
Test D & $1,2,3$ & Yes & $1,2,3$ & $1,2,4,6$ \\
\hline
\end{tabular}

No. 2 pile, and No. 3 pile) of Test D are shown in Figure 2. The interval times between first grouting and second grouting of No. 1, No. 2, and No. 3 piles were $7.5 \mathrm{~h}, 6 \mathrm{~h}$, and $4.5 \mathrm{~h}$, respectively. The sealing lengths were $2.5 \mathrm{~m}$.

The damage analyses of the steel floral tube with no pile, single pile, and three piles were conducted by means of the large-scale model test, and the effect of the double grouting on soil strength improvement and the stress performance of the pile were analysed. The displacement and stress transfer mechanisms of the vertical steel floral tube with double grouting were obtained under the action of the horizontal loading.

\section{Analysis of Model Test Results}

4.1. Double Grouting Performance. The changes in double grouting pressure with time for Tests $C$ and $D$ are shown in Figures 6 and 7 . The results show that the grouting pressures reach a peak and then decline rapidly for both experiments. During the double grouting process, the slurry passes under high pressure through the grouting hole and fractures the initial grouting body. The slurry expands and infiltrates the surrounding area, and the grouting pressure decreases. The peak pressure is the fracturing pressure of the double grouting. For Test $\mathrm{C}$, the fracturing pressure of the double grouting was measured as $5.9 \mathrm{MPa}$. The double grouting fracturing pressures of No. 1, No. 2, and No. 3 piles in Test D were $5.2 \mathrm{MPa}, 4.9 \mathrm{MPa}$, and $2.9 \mathrm{MPa}$, respectively. Test $\mathrm{D}$ results demonstrate that the value of the double grouting fracturing pressure is directly related to the interval time between first grouting and second grouting. The longer the interval time, the greater the double grouting fracturing pressure. The fracture and surrounding area of the soil body were expanded by the slurry during double grouting, and the grouting pressure increases or decreases slightly during grouting, and this pressure was called fracturing pressure of the soil body. Soon afterward, the grouting pressure tends to be flat, and the test is over.

During these two experiments, grouting fracturing was achieved by the steel floral tube micropile, but the characteristics of the slurry diffusion were not consistent. The single pile was selected for Test $\mathrm{C}$, the double grouting holes were fractured $50 \mathrm{~s}$ after the test start, and the grouting pressure rapidly decreased to $2 \mathrm{MPa}$. The grouting pressure fluctuated little, and the test was stopped until the slurry came from the bottom of the loading plate and the lower slope surface at the same time. The entire grouting lasted $13 \mathrm{~min}$, and the grouting mass exceeded $1.2 \mathrm{t}$. As the test was finished, it was found that the grouting mainly distributed in the lower part of the sliding surface. Under the action of the grouting pressure, the slurry fractured the soil and formed a root-like concrete column in the lower part of the pile, with a local thickness of $10 \mathrm{~cm}$. Test D was a combination of three steel tube piles. The fracturing grouting sequence was No. 3 pile, No. 2 pile, and No. 1 pile. As shown in Figure 7, the double grouting pressures of the three piles reached the maximum at $50 \mathrm{~s}$ after the start of grouting, followed by decreasing grouting pressures, indicating that the first grouting body was successfully fractured. The grouting 


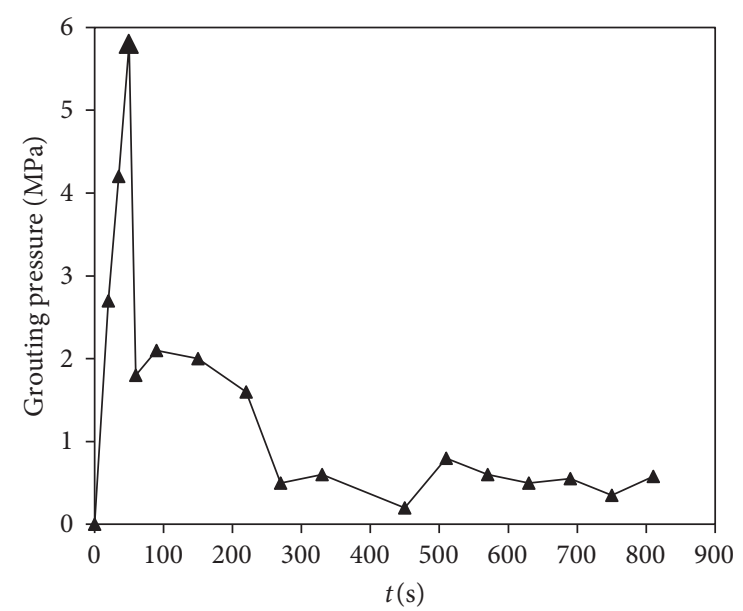

Figure 6: Double grouting pressure over time for Test C.

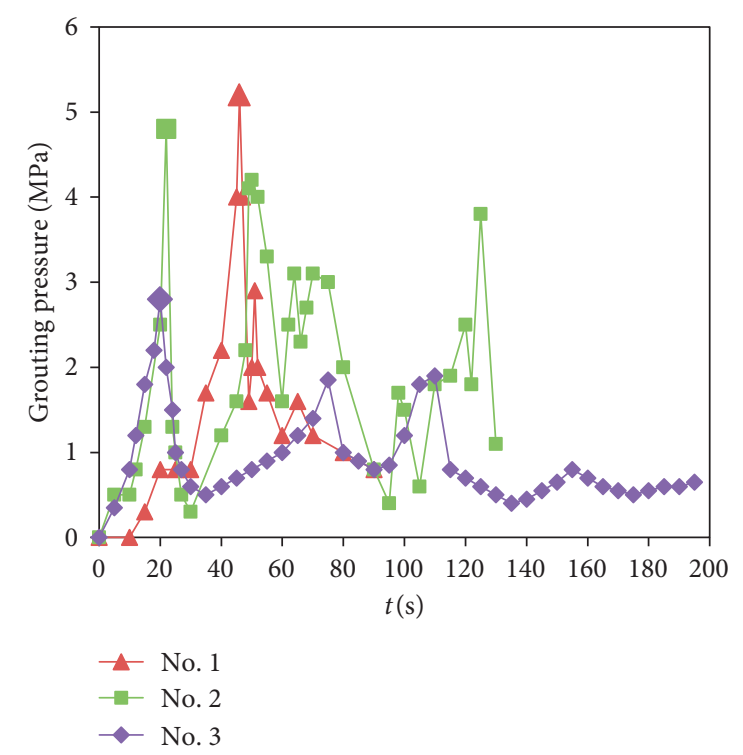

Figure 7: Double grouting pressure over time for Test D.

durations of the three fracturing tests were less than $4 \mathrm{~min}$, and the total grouting amounts were less than $0.7 t$. During the three tests, the slurry fastly gushed from the slope top. As the tests finished, it was found that the grouting mainly distributed in the lower part under the sliding surface and the fractures surrounding double grouting hole. The preset grouting pressure basically meets the test demand, and the effect of grouting pressure corresponds well to the test theory.

The results of these two tests show that the perforated pile made of the vertical steel floral tube and double grouting technology can be used to form grouting with a large diffusion area. The high pressure fractures the initial grouting and the double grouting with the formation of large diffusion area around the steel floral tube, reinforcing the soil between piles.

4.2. Analysis of Horizontal Bearing Capacity. The displacement loading was selected for a given test, and the loading process was used to ensure the load plate moved with a certain displacement. The horizontal thrust, $P$, was measured by the pressure gauges installed in the jacks, i.e., $P=P_{1}+$ $P_{2}+\ldots+P_{n}$ (where $n$ is the number of jacks and $P_{i}$ is the jack pressure). The variations of landslide thrust under loading displacement for four tests were obtained ( $P$-S curve), as shown in Figure 8. The upper part of the slope, i.e., the soil above the horizontal sliding surface, presents plastic deformation as the horizontal thrust reaches a critical value, meaning that the horizontal displacement of the loading plate continued to increase while the horizontal thrust was unchanged. In Test $\mathrm{A}$, the $P-S$ curve is approximately a straight line with a load displacement less than $220 \mathrm{~mm}$. As the load displacement exceeded $220 \mathrm{~mm}$, the upper part of the slope presented as a plastic state, and the horizontal thrust was $691.88 \mathrm{kN}$. In Test B, the plastic state appeared with a loading displacement of $380 \mathrm{~mm}$. In addition, the critical horizontal thrust was $776.16 \mathrm{kN}$, which is $84.28 \mathrm{kN}$ greater than the horizontal thrust measured in Test A; this indicates that a single steel floral tube with one grouting provides a horizontal sliding resistance of $84.28 \mathrm{kN}$. In Test $\mathrm{C}$, the plastic state appeared as the loading displacement reached $340 \mathrm{~mm}$, and the critical horizontal thrust was $796.74 \mathrm{kN}$. According to the comparison between Test B and Test $\mathrm{C}$, it is found that the required loading displacement decreases for the upper part of the slope reaching the plastic state, which means the enhancement of the single pile stiffness. Compared with Test B, the horizontal thrust provided by the pile in Test C increased by $20.58 \mathrm{kN}$, corresponding to an increase in the horizontal bearing capacity of $24.42 \%(20.58 \mathrm{kN} / 84.28 \mathrm{kN}=24.42 \%)$. Test $\mathrm{D}$ reached the plastic state at a loading displacement of $500 \mathrm{~mm}$, and the critical horizontal thrust was $1070.16 \mathrm{kN}$. Moreover, the horizontal antislip force of the three piles was approximately $378.28 \mathrm{kN}(1070.16 \mathrm{kN}-691.88 \mathrm{kN}=378.28 \mathrm{kN})$, which is three times that of the single pile with one grouting $(3 \times$ $104.86 \mathrm{kN}=314.58 \mathrm{kN})$. Therefore, the horizontal bearing capacity increased by $20.25 \%((378.28 \mathrm{kN}-314.58 \mathrm{kN}) /$ $314.58 \mathrm{kN}=20.25 \%)$. The test results show that the double grouting technology can reinforce the soil between piles and improve the mechanical performance of the steel floral tube group as well as improve the horizontal bearing capacity of the steel floral tube pile.

4.3. Analysis of Soil Pressure. Soil pressure was monitored by the soil pressure gauge embedded in the model tank. The layout of the soil pressure gauge and the experimental protocol are shown in Figure 2 and Table 1, respectively. Changes in soil pressure with depth are shown in Figures 9-12. The results show that the maximum soil pressure above the sliding surface (the sliding surface is located at the depth of $3 \mathrm{~m}$ ) appeared at the depth of 2-2.5 m away from the sliding surface top, under the condition of displacement loading. In addition, the smaller the distance to the loading plate, the larger the soil pressure. Below the sliding surface, the soil pressure gradually decreased with increasing depth. The distribution of soil pressure as Test A reached the plastic critical state is depicted in Figure 9. 


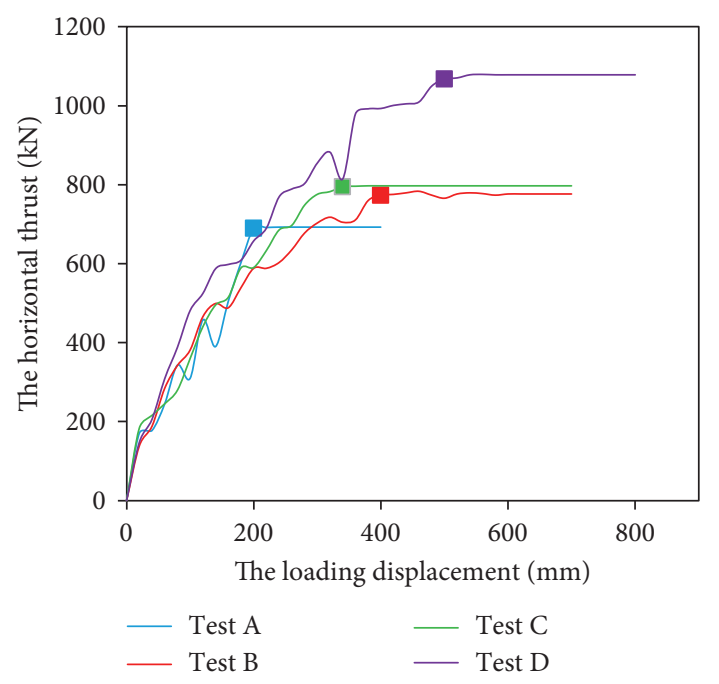

FIGURE 8: Variation of horizontal thrust with loading displacement.

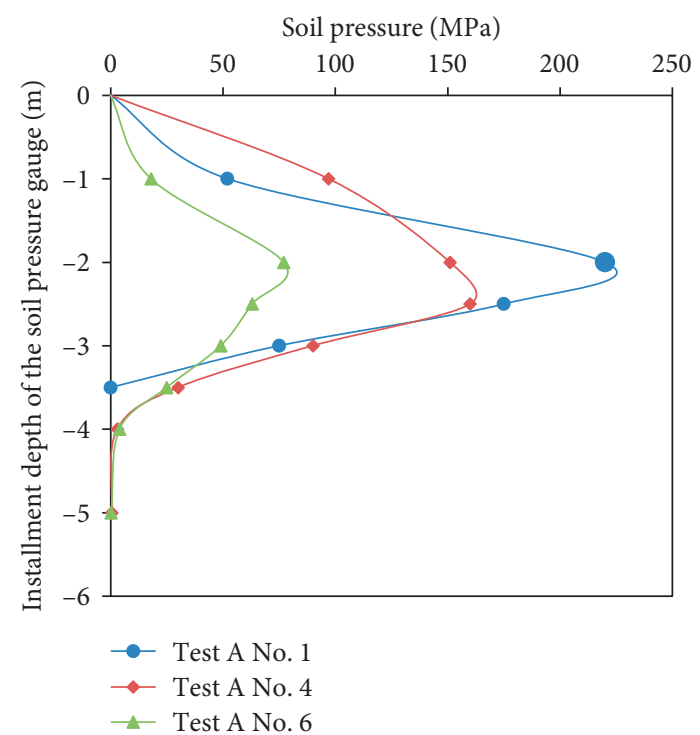

FIGURE 9: Variation of soil pressure with installment depth for Test A.

During the test process, three soil pressure gauges were embedded. The maximum soil pressure of $221.0 \mathrm{kPa}$ occurred at the row nearest the loading plate, which is located at the distance of about $2 \mathrm{~m}$ away from the top of the slope surface.

As shown in Figure 10, the first row of piles in Test B reached a maximum soil pressure of $595 \mathrm{kPa}$, which was 2.7 times greater than the soil pressure of the second row of piles $(220 \mathrm{kPa})$. This represents an increase of $274 \mathrm{kPa}$ or $124 \%$ when compared with Test A ( $221 \mathrm{kPa})$. Moreover, it can be suggested that the steel floral tube micropile plays a role in resisting the horizontal thrust. In addition, the soil pressure below the sliding surface is higher than that of Test $\mathrm{A}$ without piles, and the pile can transfer the upper landslide thrust to the rock-soil body of the lower part of the sliding bed.

As shown in Figure 11, the maximum soil pressure of the first row of piles in Test $C$ reached $775 \mathrm{kPa}$, which was 1.96 times greater than the second row $(395 \mathrm{kPa})$. Compared with

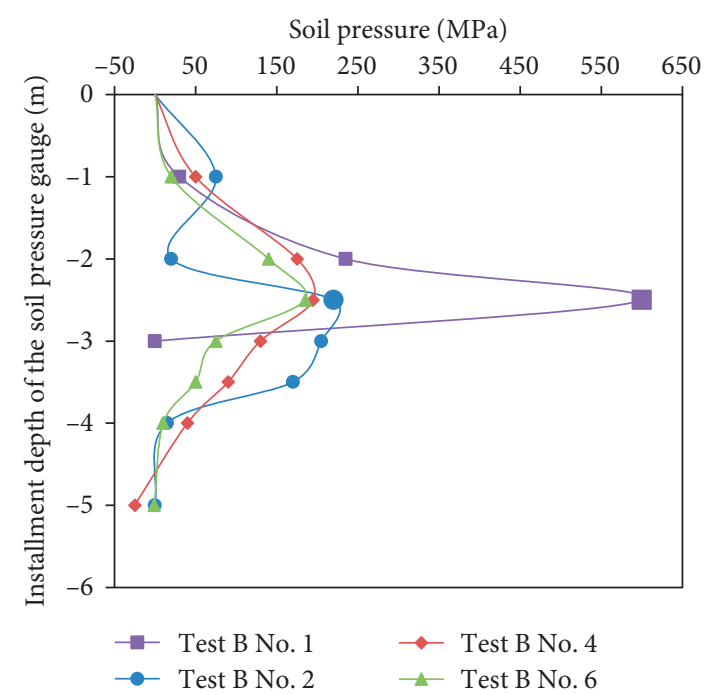

FIGURE 10: Variation of soil pressure with installment depth for Test B.

Test A, the maximum soil pressure of Test $\mathrm{B}$ at the same position increased by $554 \mathrm{kPa}$ or $251 \%$; this also represents an increase of $180 \mathrm{kPa}$ or $30 \%$ when compared with Test B. Therefore, double grouting increases the capacity of the steel tube pile to resist horizontal thrust. In addition, the soil pressure below the sliding surface was significantly larger than that in Test $\mathrm{B}$, and the double grouting enhanced the downward conduction of soil pressure.

Figure 12 shows the distribution of soil pressure with the plastic critical state for Test D. The distribution of soil pressure in the front and back of each row of piles was similar to that of the single-pile test (Test C), but the overall soil pressure was improved.

For Test D, the maximum soil pressure in front of No. 1 pile reached $1100 \mathrm{kPa}$; this is $42 \%$ higher than the soil pressure in front of the pile in Test $\mathrm{C}$. The three rows of piles in Test $\mathrm{C}$ collectively improved the mechanical state of soil and the soil pressure in front of No. 1 pile. With respect to future engineering application, these results indicate that the structure of the first row of piles can be changed to improve its performance.

The test results show that the vertical steel floral tube micropile can improve the soil strength of a slope within the grouting range. Under conditions of similar displacement, the grouting area, with high soil strength, can easily produce the stress concentration and share the large landslide thrust. Compared with conventional steel floral piles, the double grouting causes the action point of a landslide thrust to move farther down and improves the action of landslide thrust.

4.4. Analysis of Bending Moment. The size of the steel floral tube micropile was $89 \times 4.5 \mathrm{~mm}$, and cement slurry with a grade of P.O 42.5 and strength of $42.5 \mathrm{MPa}$ was selected as the grouting material. According to the Code for Design of Concrete Structures GB50010-2010, the flexural capacity of concrete with a circular section is as follows: 


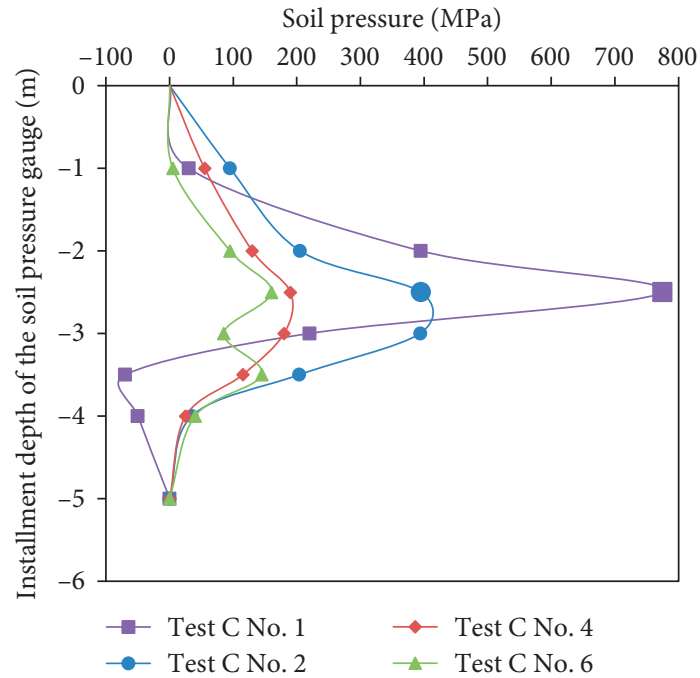

FIGURE 11: Variation of soil pressure with installment depth for Test C.

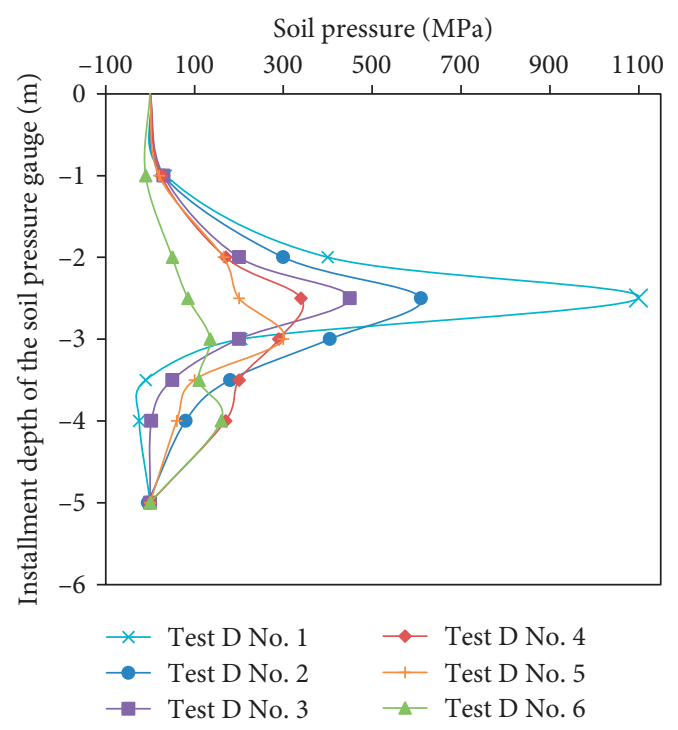

FIGURE 12: Variation of soil pressure with installment depth for Test D.

$$
\begin{aligned}
& \sum N=0, \\
& \alpha \alpha_{1} f_{\mathrm{c}} A\left(1-\frac{\sin 2 \pi \alpha}{2 \pi \alpha}\right)+\alpha f_{\mathrm{y}} A_{\mathrm{s}}=\alpha_{\mathrm{t}} f_{\mathrm{y}} A_{\mathrm{s}}, \\
& M_{\mathrm{u}}=\frac{2}{3} \alpha_{1} f_{\mathrm{cm}} A r \frac{\sin ^{3} \pi \alpha}{\pi}+f_{\mathrm{y}} A_{\mathrm{s}} r_{\mathrm{s}} \frac{\sin \pi \alpha+\sin \pi \alpha_{\mathrm{t}}}{\pi}, \\
& Q=Q_{\mathrm{c}}+Q_{\mathrm{s}}=\frac{\pi d^{2}}{4} f_{\mathrm{t}}+\frac{\pi\left(d_{1}^{2}-d_{2}^{2}\right)}{4} f_{\mathrm{v}},
\end{aligned}
$$

where $N$ is the design value of the axial force, the pressure is positive and the tension is negative, $f_{\mathrm{t}}$ is the design value of the shear strength of slurry $(1.71 \mathrm{MPa}), f_{\mathrm{v}}$ is the elasticity modulus of slurry $\left(2.5 \times 10^{4} \mathrm{MPa}\right), E_{\mathrm{c}}$ is the elasticity modulus of the steel tube $\left(2.06 \times 10^{5} \mathrm{MPa}\right), d$ is the diameter of the pile $(130 \mathrm{~mm}), d_{1}$ is the external diameter of the steel tube $(89 \mathrm{~mm}), d_{2}$ is the inner diameter of the steel tube $(79 \mathrm{~mm}), f_{\mathrm{cm}}$ is the design value of the compressive strength of slurry $(19.1 \mathrm{MPa}), f_{\mathrm{y}}$ is the design value of the tensile strength of the steel tube $(310 \mathrm{MPa}), r$ is the radius of the circular cross section $(65 \mathrm{~mm}), r_{\mathrm{s}}$ is the circle radius of the gravity center of the steel tube section, $\alpha$ is the ratio of the center angle of compression surface ( $\mathrm{rad})$ and $2 \pi$, and $\alpha_{\mathrm{t}}$ is the ratio of the area of the drawn steel tube ( $\mathrm{rad})$ and the whole area of steel tube $\left(\alpha_{\mathrm{t}}=1.25-2 \alpha\right)$. By solving Equation (2), $\alpha=0.3657$ and $\alpha_{\mathrm{t}}=0.5186$. Thus, the flexural strength was calculated to be $24.30 \mathrm{kN} \cdot \mathrm{m}$ and the shear bearing capacity $260.07 \mathrm{kN} \cdot \mathrm{m}$ by substituting Equation (2) into Equations (3) and (4).

Using the data collected by the strain meter, the variation of the bending moment acting on the pile was obtained by solving the equation $M=\operatorname{EI}(\varepsilon 1-\varepsilon 2) d$, where $M$ is the bending moment $(\mathrm{kN} \cdot \mathrm{m}), \varepsilon$ is the strain, $d$ is the distance between measuring points ( $\mathrm{m}$ ), and EI is the flexural rigidity of the pile $(\mathrm{kN})$. As shown in Figures 13-17, the bending moment of each pile increases with increasing loading displacement. Additionally, the upper part of the sliding surface close to the loading plate is pressed, and the lower part of the sliding surface near the loading plate is drawn. The positions of the maximum bending point and the reverse bending point (the bending moment is 0 ) are almost unchanging. In addition, the bending moment on both sides of the reverse bending point presents as parabolic forms. Based on the experimental data, the maximum bending moment of the pile was not precisely located on the sliding surface. The maximum bending moment above the sliding surface is located at a depth of $2.0-2.5 \mathrm{~m}$ from the pile top, and the maximum negative bending moment below the sliding surface is located at a depth of $4 \mathrm{~m}$ from the pile top, which are the weakest parts of the pile. With respect to engineering practice, the design of the flexural rigidity should be enhanced.

As shown in Figure 13, the positive moment of the steel floral tube in Test B is $13.3 \mathrm{kN} \cdot \mathrm{m}$ as the loading displacement reaches $140 \mathrm{~mm}$, and the maximum bending moment is located at a position $4 \mathrm{~m}$ away from the pile top. As the loading displacement reached $160 \mathrm{~mm}$, the strain gauge at the abovementioned position was damaged, suggesting that the pile was also damaged. According to the test results, the ultimate bending moment of the steel floral tube micropile reached $13.3 \mathrm{kN} \cdot \mathrm{m}$ under the condition of the single pile with one grouting.

As shown in Figure 14, the positive moment of the steel floral tube in Test $\mathrm{C}$ was $22.9 \mathrm{kN} \cdot \mathrm{m}$ as the loading displacement reached $180 \mathrm{~mm}$, and the negative bending moment reached $19.9 \mathrm{kN} \cdot \mathrm{m}$, which are close to the ultimate bending moment of $24.3 \mathrm{kN} \cdot \mathrm{m}$. As the loading displacement reached $200 \mathrm{~mm}$, the maximum bending moment exceeded the ultimate value. Also, the bending moment above the reverse bending point reached $24.1 \mathrm{kN} \cdot \mathrm{m}$, and the bending moment below the reverse bending point reached $26.1 \mathrm{kN} \cdot \mathrm{m}$, suggesting that the pile was damaged. The bending moment distributions of Tests $B$ and $C$ are similar, but the ultimate 


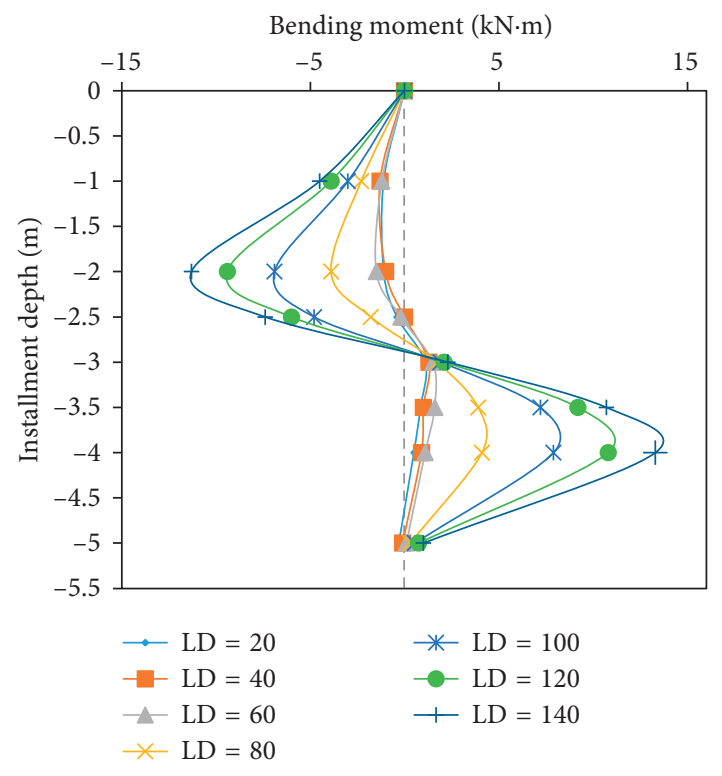

FIGURE 13: Variation of bending moment with installment depth for Test B (loading displacement short for LD).

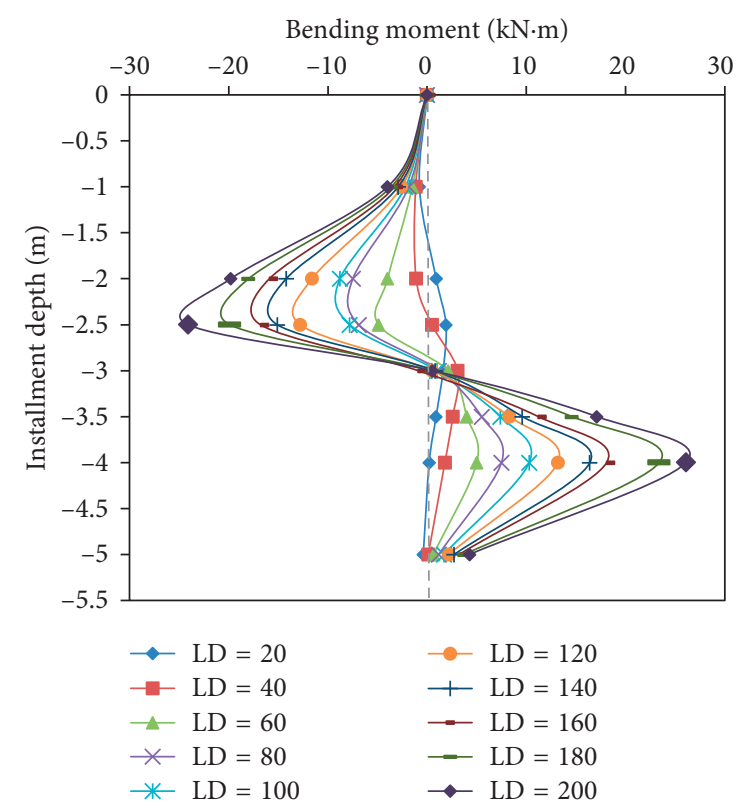

FIGURE 14: Variation of bending moment with installment depth for Test C (loading displacement short for LD).

bending moment of the single pile increased by $12.8 \mathrm{kN} \cdot \mathrm{m}$ owing to the double grouting, and the bending resistance significantly increased by $96.2 \%$.

Figures 15 to 17 show the bending moment variation of three piles during the loading process. As displayed in Figures 14 and 15, the bending moment distributions of No. 1 pile and No. 2 pile were similar. The upper part of the sliding surface close to the loading plate is pressed, located at a distance of 1-3 $\mathrm{m}$. Also, the lower part of the sliding surface near the loading plate is drawn. The bending moment of the upper and lower parts of the sliding surface for No. 1 pile

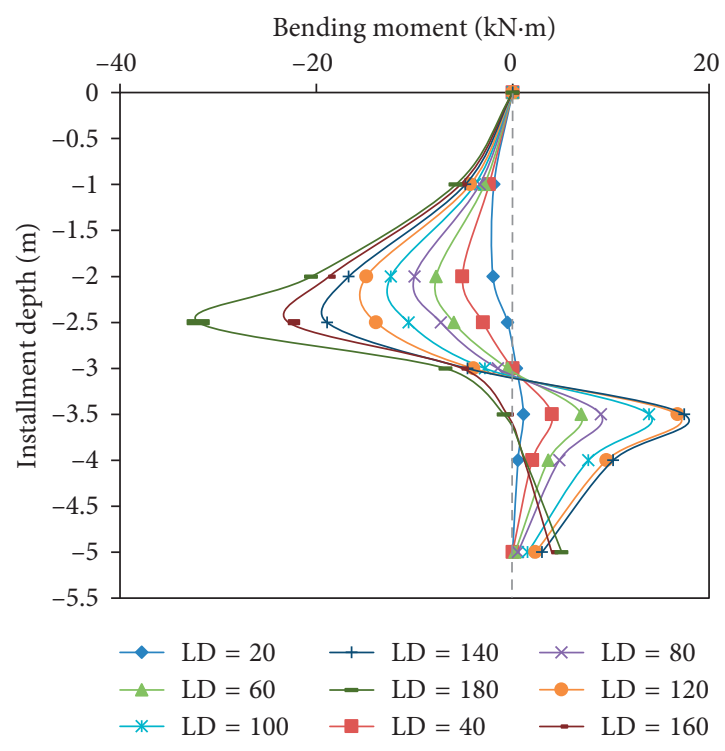

FIGURE 15: Variation of bending moment with installment depth for Test D No. 1 (loading displacement short for LD).

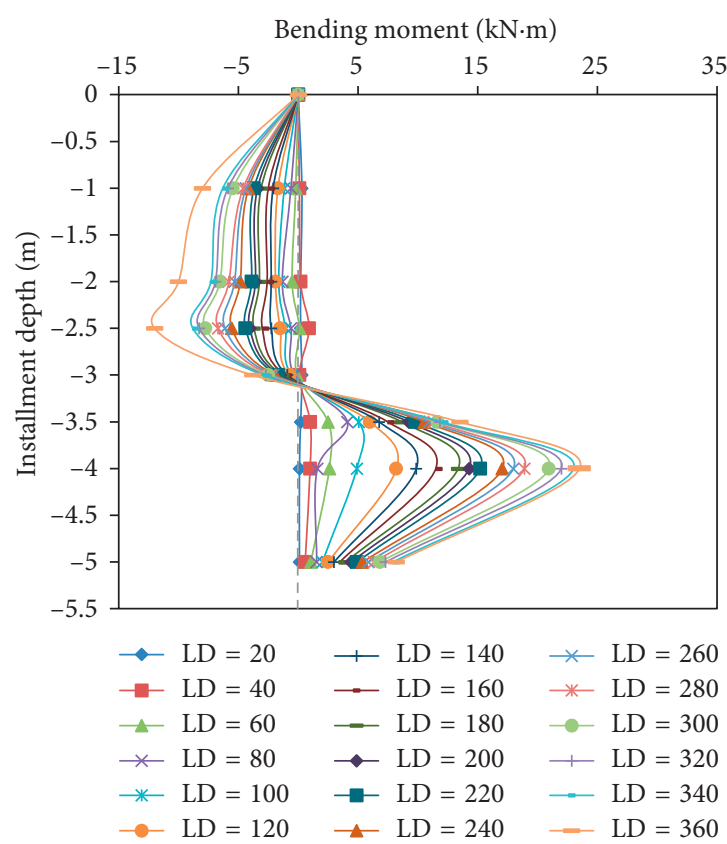

FIGURE 16: Variation of bending moment with installment depth for Test D No. 2 (loading displacement short for LD).

were similar, and the maximum bending moment of the lower part of the sliding surface for No. 2 pile was significantly larger than that of the upper part. As shown in Figure 14, the maximum bending moment was $22.8 \mathrm{kN} \cdot \mathrm{m}$ as the loading displacement of No. 1 pile reached $160 \mathrm{~mm}$, which is close to the ultimate value. As the loading displacement reached $180 \mathrm{~mm}$, the strain gauge below the reverse bending point was damaged, and the maximum negative bending moment above the reverse bending point was $32.00 \mathrm{kN} \cdot \mathrm{m}$. Also, the bending moment acting on the pile was $7.7 \mathrm{kN} \cdot \mathrm{m}$ larger than the ultimate value, and the pile 


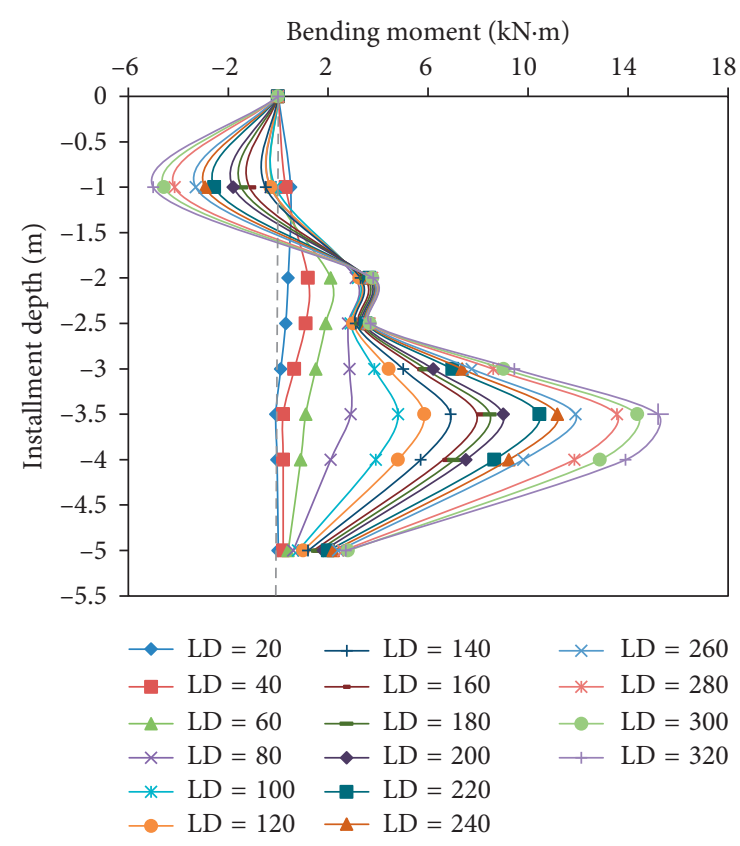

FIGURE 17: Variation of bending moment with installment depth for Test D No. 3 (loading displacement short for LD).

was damaged. For both Test $\mathrm{C}$ and Test $\mathrm{D}$, the maximum bending moment of No. 1 pile was similar, with the loading displacement of $160 \mathrm{~mm}$. The maximum bending moment for No. 1 pile was $22.9 \mathrm{kN} \cdot \mathrm{m}$ in Test C and $22.8 \mathrm{kN} \cdot \mathrm{m}$ in Test D. Thus, the bending resistances for these two tests were similar. As shown in Figure 15, the maximum bending moment of No. 2 pile reached $24.5 \mathrm{kN} \cdot \mathrm{m}$ with the loading displacement of $360 \mathrm{~mm}$, and the pile was damaged. As shown in Figure 16, the strain gauge at the depth of $4 \mathrm{~m}$ was damaged as the loading displacement reached $320 \mathrm{~mm}$, and the pile was damaged. After the damaging of No. 1 pile, No. 2 pile and No. 3 pile still presented good bending resistance. Moreover, the loading displacement of No. 2 pile increased by 1.8 times as No. 1 pile, and the loading displacement of No. 3 pile increased by 1.6 times as No. 1 pile. Therefore, it can be concluded that the bending resistance of the pile group with three piles is larger than the bending resistance of a single pile.

\section{Conclusions}

A micropile of a steel floral tube with double grouting was developed based on the traditional steel tube technology. The performance of this technology to improve the horizontal bearing capacity of the pile and improve the reinforcement of soil between piles, as well as the shear and bending performances of the pile, was investigated using a large-scale test of the model tank. The following conclusions from this study can be drawn:

(1) The initial grouting is fractured by the double grouting owing to high pressure inside the tube. A large diffusion area is formed surrounding the steel floral tube, which strengthens the soil between piles and improves the mechanical performance of the soil. The peak value of the grouting pressure during the double grouting process is defined as the fracturing pressure. According to the test results, there is a direct relationship between fracturing pressure of the double grouting and interval time between first grouting and secondary grouting. The longer the interval time, the greater the fracturing pressure.

(2) The technology of the double grouting improves the mechanical performance of the pile group and the horizontal bearing capacity of the steel floral tube pile. Compared with traditional single grouting, the horizontal bearing capacity of the single pile with double grouting increased by $24.4 \%$. Moreover, the horizontal bearing capacity of the pile group with three piles was stronger, as demonstrated by an increase of $20.25 \%$ compared with the horizontal bearing capacity of the single pile.

(3) The test results show that the maximum soil pressure in the slope occurs at a depth of $2-2.5 \mathrm{~m}$ from the slope top, namely, the middle-upper part of the slope. The soil pressure above the sliding surface presents as a trapezoid distribution, and the soil pressure below the sliding surface is small and distributes in the form of a triangle. In the single-pile test, the maximum value of soil pressure at the same position was significantly increased by the double grouting. Soil pressure for the double grouting test was 251\% greater than that of the no-pile test and 30\% greater than that of the traditional single-pile test. For a three-pile test, the pile group improved the mechanical performance of the soil. In addition, the maximum soil pressure in front of the first row of piles increased by $42 \%$ compared with the single-pile test. The action point of landslide thrust with double grouting moved down, improving the resistance to horizontal thrust.

(4) A bending moment test demonstrated that the maximum bending moment of the pile is not precisely located at the sliding surface. The maximum positive and negative bending moments are located at positions away from the top and bottom of the sliding surface, respectively. The maximum bending moment above the sliding surface is located at the depth of 2.0-2.5 $\mathrm{m}$ away from the pile top, and the maximum negative bending moment below the sliding surface is located at the depth of $4.0 \mathrm{~m}$ away from the pile top. With the application of double grouting, the ultimate bending moment of the single pile increased by $12.8 \mathrm{kN} \cdot \mathrm{m}$, and the bending resistance increased by $96.2 \%$. It can be concluded that the flexural performance of the pile group is better than that of the single pile. During the loading process, the back two rows of piles still demonstrate improved bending performance after the failure of the first row of piles.

\section{Data Availability}

The data used to support the findings of this study are available from the corresponding author upon request. 


\section{Conflicts of Interest}

The authors declare that there are no conflicts of interest regarding the publication of this paper.

\section{Acknowledgments}

The authors would like to thank Professor Zhang Yufang, Associate Professor Wei Shaowei, and all other staff for their suggestions and assistance in the preparation of the experiments. The authors are grateful for the financial support from the National Natural Science Foundation of China (nos. 41772320 and U1402231) and Opening Research Fund of the National Engineering Laboratory for Surface Transportation Weather Impacts Prevention (no. NELXX201603).

\section{References}

[1] T. Armour, Micropile Design and Construction Guidelines Implementation Manual, , Publication NO. FHWA-SA-97070, Federal Highway Administration, Washington, DC, USA, 2000.

[2] D. R. M. Awad, "Lateral load tests on mini-piles," Islamic University Journal, vol. 7, no. 1, pp. 15-33, 1999.

[3] R. Cantoni, T. Collotta, V. N. Ghionna, and P. C. Moretti, “A design method for reticulated micropile structures in sliding slopes," Ground Engineering, vol. 22, no. 4, pp. 41-47, 1989.

[4] G. Wayne, "Anchored geo-support systems for landslide stabilization," Doctor Dissertation of University of Wyoming, University of Wyoming, Laramie, WY, USA, 2001.

[5] G. G. Meyerhof, V. Sastry, and A. S. Yalcin, "Lateral resistance and deflection of flexible piles," Canadian Geotechnical Journal, vol. 25, no. 3, pp. 511-522, 1988.

[6] T. Armour, Mircropile Design and Construction Guidelines Implementation Manual Priority Technologies (PTP) Project, Publication NO. FHWA-SA-97-070, Federal Highway Administration, Washington, DC, USA, 2000.

[7] M. J. Thompson and D. J. White, "Design of Slope reinforcement with small-diameter piles," in Proceedings of 2006 Geoshanghai International Conference, pp. 67-73, Shanghai, China, 2006.

[8] R. L. Mokwa and J. M. Duncan, "Laterally loaded pile group effects and p-y multipliers," Journal of Geotechnical Special Publication, vol. 113, pp. 728-742, 2001.

[9] S. J. Lee, "Behavior of a single micropile in sand under cyclic axial loads," Doctor Dissertation of University of Illinois, University of Illinois, Urbana, IL, USA, 2004.

[10] A. Benslimane, Dynamic Behavior of Micropiles Systems Subjected to Sinusoidal Ground Motion, Doctor Dissertation of Polytechnic University, pp. 1-2, 2000.

[11] JAMP, Design and Execution Manual for Seismic Retrofitting of Existing Pile Foundation with High Capacity Micropiles, Foundation Engineering Research Team, Structures Research Group, Public Works Research Institute, Japan, 2002.

[12] T. D. Richards Jr. and M. J. Rothbauer, "Lateral loads on pin piles (micropiles)," in Proceedings of Sessions of the Geosupport Conference: Innovation and Cooperation in Geo, vol. 1, no. 7, pp. 158-174, Geotechnical Special Publication, ASCE, Reston, VA, USA, 2004..

[13] J. Long, M. Maniaci, G. Menezes, and R. Ball, "Results of lateral load tests on micropiles," Geotechnical Special Publication, vol. 1, no. 4, pp. 122-133, 2004.
[14] A. S. Yalcin and G. G. Meyerhof, "The effect of installation on the ultimate resistance of rigid piles under inclined loads in layered sand," Soils and Foundations, vol. 30, no. 3, pp. 37-52, 2008.

[15] S. H. Kim, J. Choi, J. M. Lee, J. Lee, and C. Y. Jung, "Improved load carrying behavior of perfobond rib-installed partially expanded micropiles," Geotechnical Testing Journal, vol. 39, no. 4, article 20150269, 2016.

[16] P. Yin, W. He, and Z. J. Yang, "A simplified nonlinear method for a laterally loaded pile in sloping ground," Advances in Civil Engineering, vol. 2018, Article ID 5438618, 9 pages, 2018.

[17] M. A. Kahribt and J. M. Abbas, "Lateral response of a single pile under combined axial and lateral cyclic loading in sandy soil," Civil Engineering Journal, vol. 4, no. 9, pp. 1996-2010, 2018.

[18] A. B. Dan and C. F. Shie, "Numerical experiments into group effects on the response of piles to lateral loading," Computers and Geotechnics, vol. 10, no. 3, pp. 211-230, 1990.

[19] K. M. Rollins, S. R. Johnson, K. T. Petersen, and T. J. Weaver, "Static and dynamic lateral load behavior of pile groups based on full-scale testing," in Proceedings of the 13th International Conference on Offshore and Polar Drilling, pp. 506-513, Honolulu, Hawaii, USA, 2003.

[20] K. M. Rollins, K. G. Olsen, D. H. Jensen, B. H. Garrett, R. J. Olsen, and J. J. Egbert, "Pile spacing effects on lateral pile group behavior: analysis," Journal of Geotechnical and Geoenvironmental Engineering, vol. 132, no. 10, pp. 1272-1283, 2006.

[21] J. J. Zhou, X. N. Gong, K. H. Wang, R. H. Zhang, and J. J. Yan, "Testing and modeling the behavior of pre-bored grouting planted piles under compression and tension," Acta Geotechnical, vol. 12, no. 5, pp. 1061-1075, 2017.

[22] Y. Shi, H. Wang, Y. Zhu, J. Wang, and Z. Zhang, "Threedimensional numerical analysis for the effect of micropile parameters on the stability of slopes," Journal of Zhejiang University of Technology, vol. 45, no. 3, pp. 249-252, 2017.

[23] G. Du, A. Wang, L. Li, and D. Zhang, "Calculation approach for lateral bearing capacity of single precast concrete piles with improved soil surrounds," Advances in Civil Engineering, vol. 2018, Article ID 5127927, 12 pages, 2018.

[24] B. L. Zhu and X. F. Wu, "Engineering application on steeltube bored grouting anti-sliding retaining wall in the treatment of landslide," Advanced Materials Research, vol. 261263, pp. 1872-1876, 2011.

[25] L. X. Li, C. H. Wang, T. T. Zhou, X. B. Hu, and S. L. Zhang, "Impact of position of micropile on mechanical behaviors of composite soil nailing wall curtain," Rock and Soil Mechanics, no. s1, pp. 501-505, 2015.

[26] Z. C. Zhang and Y. M. Chen, "Model test and numerical analysis of micropile-MSE wall," Chinese Journal of Rock Mechanics and Engineering, vol. 36, no. 4, pp. 987-996, 2017. 


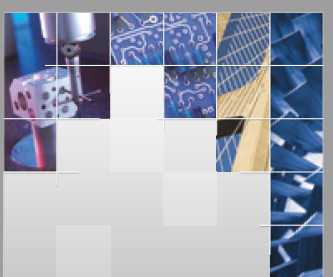

\section{Enfincering}
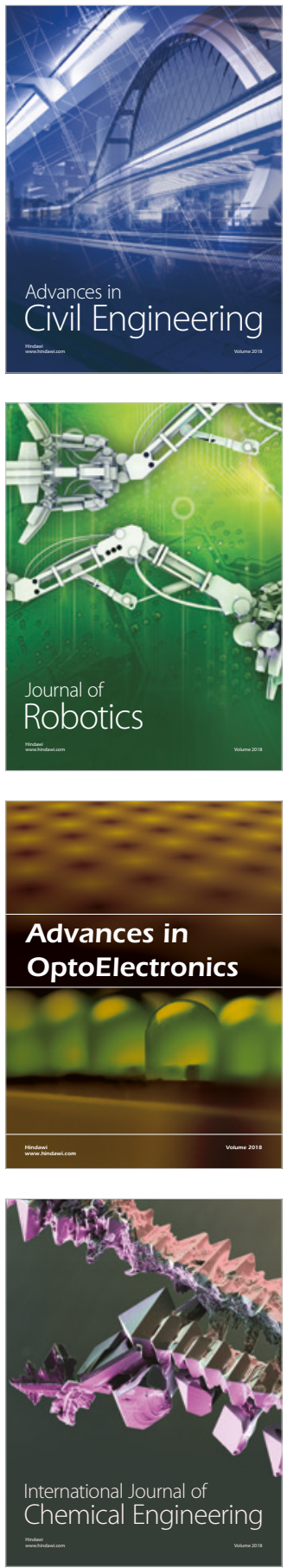

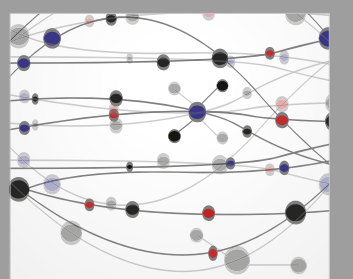

\section{Rotating \\ Machinery}

The Scientific World Journal

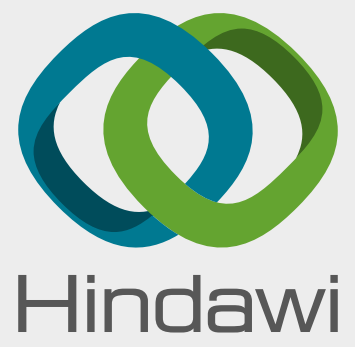

Submit your manuscripts at

www.hindawi.com
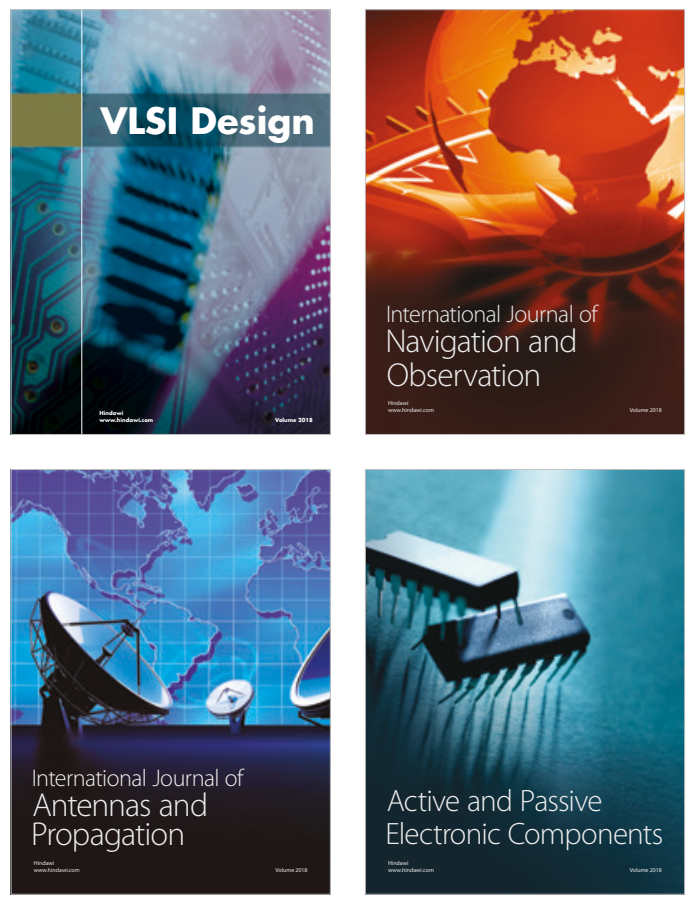
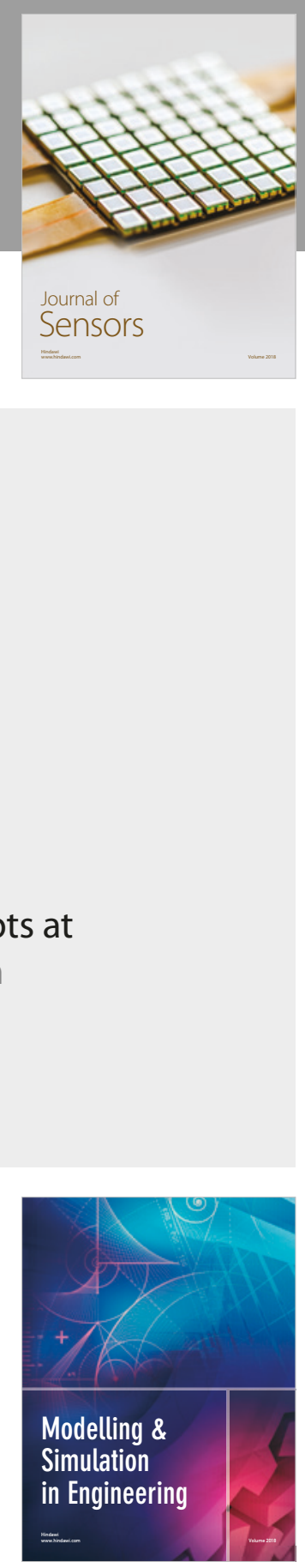

\section{Advances \\ Multimedia}
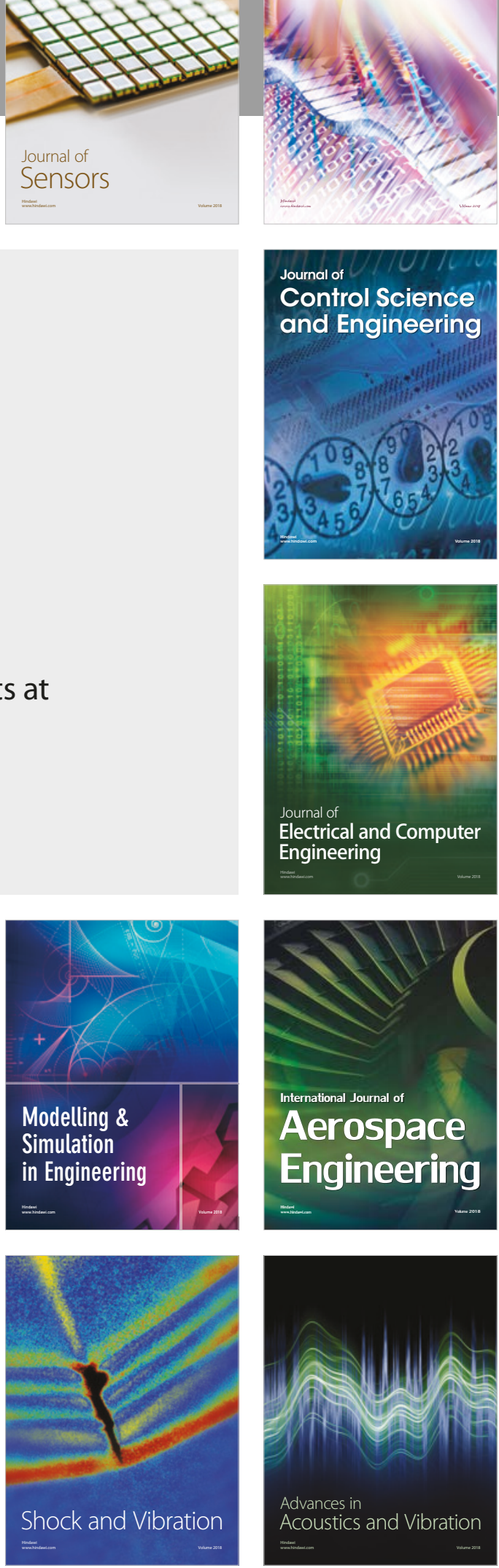